\title{
PENERIMAAN DIRI PADA PENDERITA DIABETES MELITUS PASKA AMPUTASI DI WILAYAH LOMBOK NUSA TENGGARA BARAT
}

\author{
Oleh; \\ Khairiyatul Aulia $^{1)}$, Iman Permana ${ }^{2)}$, Yanuar Primanda ${ }^{3)}$ \\ 1) Mahasiswa Program Magister Keperawatan UMY,Email: khairiyatulaulia3@gmail.com \\ 2) Dosen Program Magister Keperawatan UMY, Email: khairiyatulaulia3@gmail.com \\ 3) Dosen Program Magister Keperawatan UMY, Email: khairiyatulaulia3@gmail.com
}

\begin{abstract}
ABSTRAK
Latar Belakang; Tahap duka cita dan kehilangan pada penderita amputasi berbagai macam reaksi, sebagaian besar pada penderita amputasi akan mengalami frustasi dan fase depresi bekepanjangan yang membuat terjadinya resiko bunuh diri. Namun banyak penderita amputasi yang dapat menerima keadaan sebagai Takdir Tuhan. Tujuan penelitian ini untuk menggali persepsi penerimaan diri penderita diabetes melitus paska amputasi dalam menjalani kehidupan dengan disabilitas.

Metode; penelitan mengunakan pendekatan kualitatif dengan analisis naratif, jumlah informan terdiri dari 6 orang, dan peneliti menjadi instrument utama serta terdapatnya perekam suara, catatan lapangan, dan lembar wawancara semi terstruktur.

Hasil; hasil penelitian ini di dapatkan 5 tema yaitu a) menerima keadaan emosional, b) meyakini sebuah cobaan, c) nasib, d) belum menerima kehendak Allah sepenuhnya, e) menerima kehendak Allah. Hasil penelitian ini di pengaruhi oleh adanya budaya Sasak dan unsur agama dalam mempengaruhi persepsi penerimaan diri.
\end{abstract}

Kata kunci : Diabetes Melitus, Budaya Sasak, Penerimaan Diri 


\section{PENDAHULUAN}

Angka amputasi di dunia yaitu 0,7 dari 1000 penduduk, sedangkan di Asia 31 dari 1000 penduduk (National Diabetes Statistics Report, 2014). Berdasarkan data angka kejadian amputasi di Indonesia pada tahun 2010-2011 meningkat dari 35,5\% menjadi 54,8\% (Purwanti, 2014).

Data Survay Demografi Indonesia tahun 2007 NTB merupakan daerah ke 10 dengan angka kejadian DM dan komplikasinya. Data Rekam Medis tahun 2013 terdapat 2640 kasus di Poli RSUD NTB, sedangkan untuk kejadian DM dan komplikasinya yaitu ulkus diabetes pada tahun 2014 di rawat inap terdapat 94 pasien dan terjadi peningkatan pada tahun 2015 yaitu 132 pasien dan berdampak terhadap tindakan amputasi.

Kenyataan yang dihadapi pasien diabetes yang harus diamputasi memunculkan berbagai respon, KublerRoss membagi respon-respon tersebut menjadi beberapa tahapan seperti menolak, marah, tawar-menawar, depresi, dan penerimaan diri (Santrock, 2002). Oleh karena itu pasien perlu melalui tahap depresi dan mencapai tahap terakhir yaitu penerimaan diri. Penerimaan diri merujuk pada kepuasan hidup dan kebahagiaan seseorang yang sangat penting bagi kesehatan mental yang baik (Shepard, 1979).
Seseorang yang mampu menerima diri memahami betul kelebihan dan kelemahan dalam dirinya (Shepard, 1979). Penerimaan diri yang efektif atau acceptance terdiri dari 1) memiliki persepsi yang akurat terhadap realitas, 2) mampu mengatasi atau menangani stres dan kecemasan, 3) memiliki citra diri (self image) yang positif, 4) mampu mengekspresikan perasaan, 5) dan memiliki hubungan antar pribadi yang baik (Hasibuan, 2010).

Namun selain penderita diabtes paska amputasi dapat melewati responduka cita sehingga dapat menerima keadaan dan menjalani kehidupan, dan penerimaan diri dapat meningkatkan kualitas hidup penderita amputasi (Hasan et al, 2011; Novvida \& Syifa'a, 2007). Penderita amputasi juga mengalami frustasi dan death anxiety (Bhuvaneswar et al, 2007; Sing, 2013). Penderita amputasi yang berhenti pada tahap depresi justru memperburuk kondisi pasien yaitu akan terjadinya learned heplessness sehingga penderita amputasi tidak memiliki motivasi hidup (Lind et al, 2014). Untuk itu penelitian ini berguna untuk menggali respon kehilangan dan duka cita pada penderita diabetes melitus paska amputasi.

\section{METODE}

Penelitan ini mengunakan metode kualitatif. Teknik sampling yang 
digunakan adalah Purpusive sampling sebayak 6 orang dengan kriteria informan adalah penderita diabetes melitus paska amputasi yang bersuku Sasak, tempat tinggal di wilayah Lombok, beragama
Islam, dan merupakan pasien RSDUP NTB. Metode pengumpulan data dengan wawancara indeep interview. Analisis yang digunakan adalah analisis naratif.

\section{Hasil}

1. Karakteristik informan

Tabel 1. Karakteristik informan penelitian $(\mathrm{N}=6)$

\begin{tabular}{lcccccc}
\hline \multirow{2}{*}{ Karakteristik } & \multicolumn{7}{c}{ Informan } \\
\cline { 2 - 7 } & P1 & P2 & P3 & P4 & P5 & P6 \\
\hline Usia (tahun) & 54 & 52 & 56 & 45 & 57 & 55 \\
\hline Jenis kelamin & P & L & L & L & L & P \\
\hline Pekerjaan & Petani & PNS & Polisi & Buruh & Pedagang & Petani \\
\hline Pendidikan & SD & SMA & SMA & SMA & - & - \\
\hline Tipe diabetes & 2 & 2 & 2 & 2 & 2 & 2 \\
\hline Lama menderita & 4 bulan & 2 tahun & 2 tahun & 1 tahun & 2 Bulan & 1 \\
amputasi & & & & & & Bulan \\
\hline Jenis amputasi & Jari kaki & Ray & Atas lutut & transmeta & transmeta & Jari \\
& & & & tarsal & tarsal & kaki \\
\hline
\end{tabular}

Semua informan memiliki usia berada pada tahap usia lansia pertengahan (middle age) dengan riwayat penyakit DM tipe 2. Sebagian besar karakteristik informan pada penelitian ini berjenis kelamin lakilaki, tingkat pendidikan sekolah menengah atas (SMA), bekerja sebagai pekerja informal yakni buruh, dan lama amputasi yang telah dijalani informan terhitung dari bulan maret 2017 yaitu terdapat informan yang baru menjalani amputasi selama 2 bulan dan paling lama menjalani amputasi selama 2 tahun yang lalu dengan jenis amputasi paling banyak yaitu amputasi jari kaki.

2. Hasil Kualitatif

Penerimaan diri dapat diartikan sebagai suatu sikap positif terhadap dirinya sendiri, menerima keadaan baik itu kelebihan ataupun kekurangan, adanya kesadaran penuh 
tentang siapa mereka, dan apa diri mereka, adanya kenyakinan dalam menghadapi kehidupan, berani bertangung jawab terhadap perilakunya dimasa lalu, dan menerima keadaan emosi. Persepsi informan dalam Penerimaan diri pada penelitian ini yaitu terdapat 5 tema adalah a) menerima keadaan emosional, b) meyakini sebuah cobaan, c) nasib, d) belum menerima kehendak Allah sepenuhnya, e) menerima kehendak Allah.

Penerimaan diri pada informan ini adalah penerimaan diri yang positif, dapat digambarkan adanya tahap duka cita yaitu menerima, sedangkan terdapat satu informan yang masih dalam fase depresi

a. Menerima keadaan emosional Menerima suatu keadaan emosional diartikan sebagai tidak terdapatnya tekanan emosi dan dapat mengatur emosi diri sendiri. Menerima keadaan emosi pada informan terlihat dari adanya pertanyaan yang mengacu kepada "apakah Anda marah kepada Tuhan atau orang lain terhadap kejadian amputasi?”, semua informan memberikan jawaban yakni tidak menyalahkan atau terdapat ungkapan "tidak menyalahkan". Adapun ungkapan informan sebagai berikut:

"Gak ada mba, kesal gemana, saya gak bisa menyalahkan siapa siapa atau $\operatorname{kesal}(P 1)$

“..menyalahkan siapa itu, baik Allah atau orang itu gak ada sama sekali” (P2)

b. Meyakini sebuah cobaan

Persepsi informan bahwa amputasi yang dialami tersebut merupakan suatu cobaan atau ujian atau azab, cobaan dari Allah, pernyataan ini muncul pada informan ketika peneliti menayakan mengenai "apakah amputasi ini merupakan suatu azab, cobaan dalam kehidupan?" terdapat 4 informan yang menjawan cobaan dan terdapat responden yang mengangap azab atau peringatan dari Allah. Adapun ungkapan informan sebagai berikut:

" jadi kalu memang ini teguran, azab kek namanya, terutama dikaitkan dengan penyakit dan cobaan, ekonomi, sosial..."(P2)

"...amputasi saya ini peringatan dari Allah..”(P3)

"Kalau menurut saya ini suatu cobaan dari Allah.., "(P4) 
c. Nasib

Nasib dalam konteks ini berbeda dengan pasrah lebih cenderung kearah takdir yang didapat, atau suatu ketetapan. Nasib sendiri di persepsikan oleh informan sebagai takdir, kehendak, dan menerima kejadian amputasi dengan ikhlas, terdapat 4 orang yang menyatakan nasib dan terapat juga ungkapan kehendak Allah dan kata penekanan endek ulaq atau berpikir yang positif. Adapun ungkapan ini sebagai berikut:

"Jadi nasib kita ini sudah ditentukan, sekarang langkah kita sudah ditentukan oleh Allah..."(P3)

"Kita gak boleh melawan kehendak Allah ta'ala..."(P4)

"ndek ulaq tepikiran siq lenge tipak sai- sai, terlebih tipak si Allah ta'ala, "(P6)

d. Belum menerima kehendak Allah sepenuhnya

Penerimaan diri terhadap kejadian amputasi diungkapkan oleh satu informan yang menyatakan belum sepenuhnya menerima kehendak Allah yang ditunjukan sering munculnya rasa cemas, takut dan gelisah, jika melihat luka akibat amputasi, adapun ungkapan informan

tersebut sebagai berikut:

"Belum menerima, saya masih berpikir kenapa saya begini, kok saya sendiri begini, kenapa saya aja yang begini, saya takut mba sedih juga,,,("Pl)

Ungkapan ini mungacul karena adanya pengalaman yang buruk tentang pengobatan yang dijalani, dan belum memiliki pengalaman sama sebelumnya, menyatakan bahwa hal ini merupakan suatu yang buruk bahkan informan P1 mengungkapkan adanya keyakinan bahwa penyakit ini bukan karena hal medis namun hal ghaib, karena dilihat dari faktor penyebab bahwa informan tidak memiliki riwayat keluarga yang terkena diabetes melitus.

Kalau dari keluarga ada yang mengidap penyakit yang sama niki?

ak ada cuma saya sendiri yang kena gini $(P 1)$

Ungkapan mengenai konsep adanya tidak menerima realita terhadap proses pengobatan sebagai berikut :

Dari saya ke rumah sakit tanjung ke mataram saya sudah takut mba, saya gak mau di amputasi, saya teriak mba, kaki saya di potong, saya nangis mba, 
saya teriak,.. sekarang masih dah takut (P1).

e. Menerima kehendak Allah

Menerima kehendak Allah adalah menerima keadaan bahwa keadaan memang amputasi, menerima kekurangan kondisi tubuh. Ungkapan informan ini mengandung makna dalam adanya realita bahwa adanya kecacatan angota fisik, dengan adanya penekanan ungkapan "terima”, "qudrat”, "Wah ngek na atau sudah waktunya" pada kelima informan. Adapun ungkapan tersebut sebagai berikut:

“...dan saya terima kaki saya diamputasi...”(P4)

" udah qudrat iradatnya dari Allah ta'ala"(P5)

"kan jak ne jari ne wah ngak na leq aku... "(P6)

\section{PEMBAHASAN}

Hasil penilitian ini mengambarkan bahwa penerimaan pasien diabetes melitus paska amputasi yaitu pada tahap penerimaan dan depresi. Kenyataan yang dihadapi pasien diabetes yang harus diamputasi memunculkan berbagai respon, Kubler-Ross membagi respon-respon tersebut menjadi beberapa tahapan seperti menolak, marah, tawar-menawar, depresi, dan penerimaan diri (Santrock, 2002).

Pasien diabetes melitus paska amputasi yang berhenti pada tahap depresi justru akan semakin memperburuk kondisi pasien, oleh karena itu pasien perlu melalui tahap depresi dan mencapai tahap terakhir yaitu penerimaan diri. Penerimaan diri merujuk pada kepuasan hidup dan kebahagiaan seseorang yang sangat penting bagi kesehatan mental yang baik. Seseorang yang mampu menerima diri memahami betul kelebihan dan kelemahan dalam dirinya.

Penerimaan diri itu sendiri yakni, memiliki sikap positif dan realistik terhadap dirinya sendiri, mengakui dan menerima berbagai aspek termasuk kualitas baik dan buruk yang ada dalam diri serta memandang positif terhadap kehidupan yang telah dijalani sehingga terwujudnya aktualisasi dari segala potensi yang dimiliki (Matyja, 2014). Penerimaan diri dikatakan baik menurut Hurlock (dalam Rizkiana, 2008) jika individu yang bersangkutan mau dan dapat memahami keadaan dirinya, bukan seperti apa yang diinginkan, harus memiliki harapan realistis, sesuai dengan kemampuan dirinya sehingga seseorang memiliki konsep yang menyenangkan dan rasional tentang dirinya.

Penerimaan diri pada pasien diabetes paska amputasi yaitu mampu 
merawat kesehatan lebih baik lagi agar menghindari kambuhnya luka atau mengurangi resiko reamputasi melalui perawatan yang tepat (Viswanathan et al., 2010). Upaya tindakan yang tepat tersebut digambarkan dengan adanya seeking health atau bentuk upaya baik dalam pengobatan tradisional, medis, dan pendekatan spiritual (Sudarma, 2008).

Agama menjadi sumber moral utama dalam kesehatan, sehat atau sakit merupakan bagian dari "Perilaku Tuhan" bagi hambanya dan "sakit adalah karena Takdir Tuhan, serta Tuhan lah yang memiliki Kemampuan untuk meyembuhkan". Keyakinan ini membuat seorang akan memiliki semangat hidup yang baik, optimis dan menjadi sumber sugesti dan motivasi yang kuat dalam diri pasien untuk hidup positif.

Berdasarkan hasil penelitian Ningsih (2008) kondisi menerima (acceptance) yang dialami oleh seluruh pasein DM dengan ulkus juga berhubungan dengan mendekatkan diri pada Tuhan dan tetap berpandangan positif pada diri. Penelitian yang dilakukan oleh Tuncay, et al. (2008) bahwa adanya hubungan antara acceptance dan penggunaan agama (religion) terhadap peningkatan kesejahteraan psikososial mereka, selain itu religion secara signifikan berkorelasi terhadap pandangan diri yang positif (positive reframing).
Penerimaan diri dipengaruhi oleh persepsi pasien mengenai dukungan yang diperoleh, dukungan pada pasien amputasi yaitu adanya realita penerimaan pada fase saat di vonis amputasi dengan adanya peran petugas kesehatan meyakinkan bahwa tindakan amputasi merupakan tindakan terbaik (Ruli dan Kristiana, 2017). Pasien paska amputasi akan menerima gambaran dirinya positif ketika ia merasa atau mempersepsikan dukungan sebagai hal yang membuatnya menjadi lebih nyaman, dirawat, dan ditolong dan adanya faktor lain yang dapat mempengaruhi penerimaan diri subjek selain persepsi dukungan sosial yaitu aspek religiusitas (Sarafino, 2011; Cristanty dan Wardhana, 2013).

Penderita DM paska amputasi yakin akan keajaiban yang diberikan Tuhan akan pemulihan keadaannya setelah diamputasi. Hal ini sejalan dengan penelitian Rahimi et al, 2013 yang mengatakan bahwa kepercayaan religius memiliki korelasi yang positif dengan kesehatan mental seperti optimism, meaningfulness of life, coping with stresses, self-acceptance, positive attitude to life dan low anxiety. Pengalaman spiritual-psychological bersama dengan komunitas religi memberikan dampak bagi individual psychological well-being. Penerimaan diri seseorang juga dapat dipengaruhi oleh pengalaman religi 
seseorang (Cristanty dan Wardhana, 2013). Penderita penyakit kronis seperti DM dan atritis rheumatoid akan mengunakan faith base dalam bentuk rasa pasrah dan menerima (Koenig et al, 2010; Hasan, 2008).

Penderita penyakit kronis membuat merasa terbiasa dengan penyakitnya dan berusaha untuk sembuh . Selain penerimaan terhadap penyakit, faktor lain yang mempengaruhi penerimaan diri yaitu keyakinan diri (Michalak et al, 2011). Bentuk keyakinan diri yang diungkapkan yaitu berusaha agar bisa sembuh, tanggung jawab diri, dan harapan (Matyja , 2014). Adanya harapan yaitu keinginan sembuh menjadi salah satu faktor yang mendorong partisipan mencari informasi tentang penyakitnya (Hasan, 2008).

Penerimaan diri pada penelitian ini di tunjukan dengan 1) menerima keadaan emosional, 2) meyakini sebuah cobaan, 3) nasib, 4) belum menerima kehendak Allahan 5) menerima kehendak Allah. Penerimaan diri merupakan pemahaman seseorang akan kekuatan dan kelemahan dalam dirinya, menerima dan menghargai segala kekurangan yang dimiliki, mengakui dan menerima seluruh aspek dalam diri, merasakan perasaan yang positif terhadap masa lalu, serta mampu menerima keadaan-keadaan emosionalnya seperti depresi, marah, dan takut tanpa menganggu well-being orang lain (Cristanty dan Wardhana, 2013).

a. Menerima keadaan emosional

Menerima keadaan emosional ditunjukan dengan tidak adanya pergejolakan tentang yang dialami dan berpikir positif. Penelitian Cristanty dan wardhana, (2013) menjelaskan adanya informan bahwa keterbatasan fisik mampu meningkatkan kekuatan dalam dirinya dan berfikiran positif. Kondisi emosi yang menyenangkan dengan tidak menunjukkan tidak adanya tekanan emosi sehingga memungkinkan individu untuk memilih yang terbaik dan sesuai dengan dirinya. Sikap yang positif dan menyenangkan yang akan mengarahkan pada pembentukan sikap individu untuk mudah menerima diri karena tidak adanya penolakan (Michalak et al, 2011).

Penyesuaian emosional terjadi setelah terjadinya fase depresi, pada fase ini akan menimbulkan rasa sabar dalam menghadapi penyakit atau adanya reaksi positif dalam pemulihan penyakit (Hasan, 2008). Kesabaran merupakan wujud mekanisme pertahanan terhadap penyakit yang berimplikasi positif, yaitu berusaha meneruskan kehidupan, dan terus berupaya mencari pengobatan, dan mengatasi masalah depresi 
(Moordiningsih, 2008; Koenig et al, 2010; Hasan, 2008).

Hal yang diungkapkan oleh Pargament (1988) bahwa manusia kembali kepada Tuhan menjadi tempat kekuatan, sedangakan Mathwes (2000) mengungkapkan bahwa keadaan emosional yang baik dalam bentuk sabar akan mendaptkan pengaruh positif dalam upaya kesehatan yaitu mengurangi depseri dan optimisme dalam mencari pengobatan.

b. Menerima sebagai cobaan

Penderita diabetes melitus paska amputasi mampu menjalani proses dalam hidupnya, akhirnya bisa menerima kecacatan mereka dengan menyakini sebuah nasib, menerima kehendak Allah dan menerima hal ini sebagai teguran. Berdasarkan hasil penelitian Cristanty dan Wardhana, (2013) informan dengan amputasi menerima kondisi mereka dengan ikhlas, percaya pada takdir, selalu optimis dan open mind.

Hal ini sesuai dengan penelitian Fitriani (2016) bahwa adanya pengaruh agama dalam filsafah kehidupan terhadap perawatan tradisional urolithiasis suku muna, peran agama dalam penyakit di dalam agama Islam di persepssikan sebagai ujian dan cobaan dari Allah SWT. Penelitian Mauk (2010) dan Sandoyo (2009) mengangap bahwa saat sakit secara spiritual akan merasa kedekatan dengan Tuhannya dan semakin nyaman dengan agamanya menimbulkan perilaku penyerahan diri dan ibadah kepada Allah dengan praktik agama.

Menurut Sarwono (2007) agama merupakan suatu simbol yang mengakibatkan adanya pandangan yang realistis bagi pemeluknya, agama memberikan motivasi yang sangat kuat untuk mendapatkan kebenaran di atas segalanya, bahkan sehat tercermin dari pengekspresian rasa syukur pujian, kepercayaan kepada Tuhan Yang Maha Esa.

c. Persepsi mengenai nasib

Persepsi mengenai nasib atau takdir mempengaruhi dari kepatuhan klien diabetes. Penelitian Ningsih (2008) dan Ibrahim et al (2015) mengungkapkan bahwa takdir itu sendiri dimaknai oleh dua hal yang berbeda pada pasien dengan diabetes dan amputasi yaitu suatu ketetapan dan mampu melakukan upaya kesehatan atau pasrah dalam konotasi pasif. Pemaknaan takdir sebagai nasib dalam term bahasa Indonesia akan memunculkan nuansa pasif dalam 
pemahamannya, karena nasib lebih merujuk pada keadaan diterima daripada menerima'. Misalnya manusia yang merasa bahwa takdirnya sama dengan nasibnya, maka manusia tersebut akan menjalani hidup dengan pasif, dalam arti tidak mau berusaha. Karena menurut pandangannya nasib manusia sudah ditentukan dan diputuskan Tuhan (Anam, 2009; Ilyas, 2006).

Selain itu, kata nasib lebih sering dikonotasikan untuk hal-hal yang negatif. Seperti kegagalan dan kemalangan. Dibuktikan dengan kebiasaan orang dalam mengungkapkan kesialan yang dialaminya dengan kata nasib. Padahal sebenarnya penyebab kesialan tersebut adalah dirinya sendiri, bukan Allah. Manusialah yang lebih sering menjerumuskan dirinya dalam keadaan malas (pasif) (Anam, 2009).

d. Belum menerima kehendak Allah

\begin{tabular}{lrr}
\multicolumn{1}{c}{ Pasien diabetes } & melitus \\
menunjukan & adanya & fase \\
pengingkaran sebelum menjalani & man \\
amputasi, yang dimanifestasikan \\
dengan ketidak percayaan terhadap \\
diagnosa penyakit yang di terima \\
karena merasa tidak mungkin \\
mendapatkan penyakit diabetes karena \\
tidak memiliki riwayat penyakit
\end{tabular}

diabetes melitus dalam keluarga, dan pasien berupaya mencari pengobatan dengan tradisional amaupun medis, dengan reaksi psikolois yaitu merasa takut dan menolak terhadap tindakan amputasi.

Suryadinata

(2012)

mengungkapkan reaksi awal pasien penderita penyakit kronis ketika pertama kali mendengar diagnosis penyakitnya adalah pengingkaran (denial) yang kemudian dimanifestasikan dengan mencari dokter atau pakar kesehatan lain yang diharapkan mampu memberi diagnosa berbeda yang lebih ringan. Reaksi berikutnya yang biasa muncul adalah perasaan marah, cemas, dan takut. Selain itu pasien diabetes melitus paska amputasi menunjukan tahap depresi ditunjukan dengan reaksi cemas, menangis, dan menyesal dialami oleh partisipan ketika mereka telah menyadari adanya perubahan pada fisiknya. Depresi muncul ketika seseorang menyadari tentang adanya kehilangan dan dampaknya (WHO, 2004).

Williamson, Schultz, Bridges, dan Behan (1994) dalam Briggs (2006) menyebutkan bahwa kesehatan mental seseorang setelah amputasi dapat dipengaruhi secara langsung oleh berbagai faktor seperti masalah- 
masalah yang mencakup aspek sosial, psikologis, keuangan, dan kesehatan.

Faktor yang menentukan dalam penerimaan diri adalah perasaan stres yang dialami oleh pasien diabetes melitus paska amputasi yaitu adanya hal yang tidak menyenangkan selama melakukan perawatan kaki yaitu masih belum menerima secara realistis bahwa dirinya mengidap penyakit diabetes melitus (Jeragh-Alhaddad \& Brock, 2015). Hal ini sesuai dengan penelitian Novvida (2007) semakin tinggi stress pada penderita diabetes mellitus, maka semakin rendah penerimaan diri sebaliknya semakin rendah stress pada penderita diabetes mellitus, maka semakin tinggi penerimaan diri.

Faktor lainnya adanya penerimaan diri yang negatif yaitu adanya komplikasi ulkus diabetikum disertai amputasi. Ulkus diabetikum merupakan salah satu komplikasi kronik DM yang paling ditakuti (Sudoyo et al, 2009). Penelitian Nizam (2014) adanya hubungan yang signifikan antara perubahan fungsi bagian tubuh terhadap citra tubuh pasien DM yang mengalami ulkus diabetikum. Penelitian Handayani (2010) mendapatkan hasil bahwa pada pasien ulkus diabetikum dengan adanya perubahan fisik dan penafsiran semua situasi tersebut sebagai hal yang negatif. Komplikasi ulkus diabetikum pada pasien DM dapat berefek pada citra tubuh mereka.

Citra tubuh adalah ide seseorang mengenai penampilan badannya dihadapan orang lain merupakan fondasi dasar dari keseluruhan kepribadian manusia (Chaplin, 2010; Melliana, 2006). Gleeson dan Frith (2006) body image atau citra tubuh merupakan produk dari persepsi yang terbentuk melalui proses bagaimana kita memandang tubuh kita dan tubuh orang lain, kemudian kita melakukan perbandingan antar kedua tubuh tersebut dan untuk selanjutnya menginternalisasi perbandingan tersebut. Berdasarkan perbandingan tersebut akhirnya akan menghasilkan pandangan tentang bentuk kita sendiri (perceived self), apakah kita akan puas dengan bentuk tubuh kita (Sofiana, Elita \& Utomo, 2012).

e. Menerima kehendak Allah

Tindakan amputasi juga memengaruhi psikologis penderita DM dalam hal pengambilan keputusan. Pengambilan keputusan ini juga meliputi penerimaan tindakan amputasi pada penderita DM. Setelah amputasi penderita juga harus dapat beradaptasi, baik dengan kondisi 
fisiknya maupun dengan lingkungannya (Ruli dan Kristiana, 2017). Perubahan-perubahan yang dialami oleh penderita DM dan usaha untuk menerima diri sepenuhnya akan kondisi fisiknya paska amputasi tak jarang membuat penderita mengalami stres namun menjadikan agama sebagai mekanisme koping sehingga dapat menerima keadaan atau kondisi mereka (Agustin, Nurachmah \& Kariasa, 2013).

\section{KETERBATASAN PENELITIAN}

Teknik sampel hanya mengunakan variasi maksimal pada pasien dengan amputasi yang beragama Islam sehingga belum menggambarkan generalisasi penelitian. Bias penelitian kualitatif ini adalah dimana peneliti sebagai instrument utama yang berprofesi perawat dapat mempengaruhi informan dalam keterbukaan dan keluesan mengungkapkan informasi. Peneliti memiliki budaya yang sama dengan informan yaitu budaya Sasak sehingga dalam perspektif pengkajian atau saat wawancara di pengaruhi oleh kecendrungan peneliti.

\section{REFERENSI}

Bhuvaneswar, C. G., Epstein, L. A., \& Stern, T. A. (2007). Reactions to amputation: recognition and treatment. Primary care companion to the Journal of clinical psychiatry, 9(4), 303.

Hasan. (2008).Pengantar psikologi kesehatan islami. Rajawali Pers

Purwanti, L. E. (2014). Hubungan Motivasi dengan Efikasi Diri Pasien DM Tipe 2 dalam Melakukan Perawatan Kaki Di Wilayah Kerja Puskesmas Ponorogo Utara. Gaster Jurnal Ilmu Kesehatan, 11(1), 68-77.

Rubin, R. R. (2000). Diabetes and quality of life. Diabetes Spectrum, 13(1), 21.

Sadikin, Laila Mufida \& Subekti, E.M.A (2013). Coping Stres pada Penderita Diabetes Mellitus Pasca Amputasi. Jurnal Psikologi Klinis dan Kesehatan Mental Vol. 02 No. 03

Salehi, S., Ghodousi, A., \& Ojaghloo, K. (2012). The spiritual experiences of patients with diabetes-related limb amputation. Iranian journal of nursing and midwifery research, 17(3), 225.

Skirven, T. M., Osterman, A. L., Fedorczyk, J., \& Amadio, P. C. (2011). Rehabilitation of the Hand and Upper Extremity, 2-Volume Set E-Book: Expert Consult. Elsevier Health Sciences.

Subandi, M. A. (2013). Psikologi Agama dan Kesehatan Mental. Pustaka Pelajar.

Yuniarti, K. W., Dewi, C., Ningrum, R. P., Widiastuti, M., \& Asril, N. M. (2013). Illness perception, stress, religiosity, depression, social support, and self management of diabetes in Indonesia. International Journal of Research Studies in Psychology, 2(1), 25-45. 
Santrock, J.W. (2002). Life span development perkembangan masa hidup (edisi 5 jilid ii). Jakarta : Erlangga

Hasibuan, C. M. (2010). Penyesuaian Diri Penderita Komplikasi Diabetes Mellitus Setelah Amputasi.

Hasan, A., Lilik, S., \& Agustin, R. W. (2013). Hubungan Antara Penerimaan Diri dan Dukungan Emosi dengan Optimisme pada Penderita Diabetes Mellitus Anggota Aktif PERSADIA (Persatuan Diabetes Indonesia) Cabang Surakarta. Jurnal Ilmiah Psikologi Candrajiwa Vol. 2 No. 2, 60-74.

Novvida, K., \& Syifa'a, R. (2007). Penerimaan diri dan stress pada penderita diabetes melitus. Skripsi. Yogyakarta: Fakultas Psikologi Dan Ilmu Budaya UII.

Singh, C. (2013). An analytic study of death anxiety among type 2 diabetes. Mediterranean Journal of Social Sciences, 4(11), 205.

Lind, M., Svensson, A. M., Kosiborod, M., Gudbjörnsdottir, S., Pivodic, A., Wedel, H., ... \& Rosengren, A. (2014). Glycemic control and excess mortality in type 1 diabetes. New England Journal of Medicine, 371(21), 1972-1982.

Matyja, K. W. (2014). Adolescent Personalities and Their SelfAcceptance Within Complete Families, Incomplete Families and Reconstructed Families. Polish Journal of applied Psychology Volume 12 (1), 59-74.

Viswanathan, V., Wadud, J.R., Madhavan, S., Rajasekar, S., Kumpatla, S., Lutale, J.K., \& Abbas, Z.G., (2010). Comparison of post amputation outcome in patients with type 2 diabetes from specialized foot care centres in three developing countries. 88: 146-150 : Diabetes research and clinical practice.

Ningsih, E.S.P.(2008). Pengalaman psikososial pasien dengan ulkus kaki diabetes dalam konteks asuhan keperawatan diabetes melitus. Depok: FIK-UI

Tuncay, T., Musabak, I., Gok, D. E., \& Kutlu, M. (2008). The relationship between anxiety, coping strategies and characteristics of patients with diabetes. Health and quality of life outcomes, 6(1), 79.

Kristiana, I. F., \& Ruri, G. T. S. (2017). Kuterima Kekuranganku (Studi Fenomenologis Deksriptif Tentang Pengalaman Psikologis Penderita Diabetes Mellitus Pasca-amputasi). Empati: Jurnal Karya Ilmiah S1 Undip, 6(1), 206-214.

Sarafino, E. P., \& Smith, T. W. (2014). Health psychology: Biopsychosocial interactions. John Wiley \& Sons.

Christanty, D. A., \& Wardhana, I. P. (2013). Hubungan Persepsi Dukungan Sosial dengan Penerimaan Diri Pasien Penderita Diabetes Mellitus Pasca Amputasi. Jurnal Psikologi Klinis \& Kesehatan Mental vol. 2 no. 2, 55-61.

Rahimi, A., Anoosheh, M., Ahmadi, F., \& Foroughan, M. (2013). Exploring spirituality in Iranian healthy elderly people: A qualitative content analysis. Iranian Journal of Nursing and Midwifery Research, 18(2), 163170 .

Koenig, H. G. (2010). Spirituality and mental health. International Journal 
of Applied Psychoanalytic Studies, 7(2), 116-122.

Pargament, K. I., Kennell, J., Hathaway, W., Grevengoed, N., Newman, J., \& Jones, W. (1988). Religion and the problem-solving process: Three styles of coping. Journal for the scientific study of religion, 90-104.

Fitriani. (2016). Studi Fenomenologi"Perawatan Tradisional Urolithiasis Suku Muna Dengan Pendekatan Transcultural Nursing". Tesis. Universitas Muhammadiyah Yogyakarta.

Ibrahim, K., Songwathana, P., \& Boonyasopun, U. (2015). Caring for Self: Perceived by Persons Living with HIV Infection in Bandung, Indonesia. GSTF Journal of Nursing and Health Care (JNHC), 3(1).

Khoirul. 2009. Mengubah Takdir. Yogyakarta: Pustaka Pelajar.

Ilyas, Yunahar. 2005. Kuliah Aqidah Islam. Yogyakarta: Lembaga Pengkajian dan Pengamalan Islam (LPPI).

Suryadinata, N. (2012). Aspek Psikologis Penderita Penyakit Kronis. Jurnal Medicinus, 2 (2).
Briggs, W. (2006). The mental health problems and needs of older people following lower limb amputation. Clinical Gerontology, 16, 155-163.

Jeragh-Alhaddad, F. B., Waheedi, M., Barber, N. D., \& Brock, T. P. (2015). Barriers to medication taking among Kuwaiti patients with type 2 diabetes: a qualitative study. Patient preference and adherence, 9, 1491.

Sudoyo, A. W., Setiyohadi, B., Alwi, I., Simadibrata, M., \& Setiati, S. (2006). Buku ajar ilmu penyakit dalam. Jakarta: Fakultas Kedokteran Universitas Indonesia, 1213-1214.

Nizam, W. K. (2014). Faktor-faktor yang mempengaruhi citra tubuh Pasien diabetes melitus yang mengalami Ulkus diabetikum. Jurnal Online Mahasiswa Bidang Ilmu Keperawatan, 1(2), 1-7.

Chaplin, J. P. (2010). Dictionary of psychology. USA: Random House Publishing Group.

Melliana, A. S. (2006). Menjelajah tubuh:perempuan dan mitos kecantikan. Yogyakarta: LKiS. 